\title{
Cyclic stretch enhances the expression of Toll-like Receptor 4 gene in cultured cardiomyocytes via p38 MAP kinase and NF- $\kappa$ B pathway
}

\author{
Kou-Gi Shyu ${ }^{1,2}$, Bao-Wei Wang ${ }^{3}$, Chiu-Mei Lin ${ }^{4}$, Hang Chang ${ }^{4 *}$
}

\begin{abstract}
Background: Toll-like receptor 4 (TLR4) plays an important role in innate immunity. The role of TLR4 in stretched cardiomyocytes is not known. We sought to investigate whether mechanical stretch could regulate TLR4 expression, as well as the possible molecular mechanisms and signal pathways mediating the expression of TLR4 by cyclic mechanical stretch in cardiomyocytes.
\end{abstract}

Methods: Neonatal Wistar rat cardiomyocytes grown on a flexible membrane base were stretched by vacuum to $20 \%$ of maximum elongation at 60 cycles/min. Western blot, real-time polymerase chain reaction, and promoter activity assay were performed. In vitro monocyte adhesion to stretched myocyte was detected.

Results: Cyclic stretch significantly increased TLR4 protein and mRNA expression after $2 \mathrm{~h}$ to $24 \mathrm{~h}$ of stretch. Addition of SB203580, TNF- $\alpha$ antibody, and p38 $\alpha$ MAP kinase siRNA 30 min before stretch inhibited the induction of TLR4 protein. Cyclic stretch increased, while SB203580 abolished the phosphorylated p38 protein. Gel shifting assay showed significant increase of DNA-protein binding activity of NF- $\kappa$ B after stretch and SB203580 abolished the DNA-protein binding activity induced by cyclic stretch. DNA-binding complexes induced by cyclic stretch could be supershifted by p65 monoclonal antibody. Cyclic stretch increased TLR4 promoter activity while SB203580 and NF- $\kappa$ B siRNA decreased TLR4 promoter activity. Cyclic stretch increased adhesion of monocyte to cardiomyocytes while SB203580, TNF- $\alpha$ antibody, and TLR4 siRNA attenuated the adherence of monocyte. TNF- $\alpha$ and Ang II significantly increased TLR4 protein expression. Addition of losartan, TNF- $\alpha$ antibody, or p38 $\alpha$ siRNA 30 min before Ang $\|$ and TNF- $\alpha$ stimulation significantly blocked the increase of TLR4 protein by Angll and TNF- $\alpha$.

Conclusions: Cyclic mechanical stretch enhances TLR4 expression in cultured rat neonatal cardiomyocytes. The stretch-induced TLR4 is mediated through activation of p38 MAP kinase and NF- $\kappa$ B pathways. TLR4 up-regulation by cyclic stretch increases monocyte adherence.

\section{Introduction}

Toll-like receptors (TLRs) are pattern recognition receptors that play an important role in the induction of innate immunity by recognition of exogenous pathogen-associated molecular patterns and endogenous ligands [1]. Innate immune and inflammatory pathways have been implicated in cardiac dysfunction after global myocardial ischemia [2]. TLR4, a member of the TLR family, is expressed on the cell surface of cardiac cells, including cardiomyocytes, smooth muscle cells, and endothelial

\footnotetext{
* Correspondence: m002018@ms.skh.org.tw
${ }^{4}$ Department of Emergency Medicine, Shin Kong Wu Ho-Su Memorial

* Correspondence: m002018@ms.skh.org.tw Hospital, Taipei, Taiwan
}

cells. Increased TLR4 expression has been observed in cardiomyocytes from human and animals with heart failure [3]. TLR4 can modulate myocyte contractility, myocardial ischemia-reperfusion injury [4,5]. TLR4 also plays a role in myocardial dysfunction during bacterial sepsis $[6,7]$, pressure overload induced cardiac hypertrophy [8], and doxorubicin-induced cardiomyopathy [9].

Cardiac myocytes have been reported to express functional TLR4 in lipopolysaccharide-treated myocytes, which can produce tumor necrosis factor- $\alpha$ (TNF- $\alpha$ ) [10] and activate NF- $\kappa$ B [11]. Raised TNF- $\alpha$ production has been reported in chronic heart failure [12]. However, the direct effect of TNF- $\alpha$ on TLR4 in cardiac myocytes is not known. 
Chronic heart failure is a state of chronic inflammation [13]. Therefore, the importance of a functionally intact innate immune system in the heart should be emphasized. Mechanical stress overload is able to induce inflammatory mediators and causes ventricular hypertrophy [14]. The cyclic strain system subjects cultured cells to repetitive stretching-relaxation at rates comparable to dynamic stretch overload in vivo. This system has been applied widely to study the molecular mechanisms of gene expression and signal transduction in many cell types [15-17]. To date, it is not reported yet whether mechanical stretch can induce expression of TLR4 in cardiomyocytes. Thus, we sought to investigate whether stretch could regulate TLR4 expression, as well as the possible molecular mechanisms and signal pathways mediating the expression of TLR4 by cyclic mechanical stretch in cardiomyocytes.

\section{Methods}

\section{Primary cardiomyocyte culture}

Cardiomyocytes were obtained from Wistar rats aged 23 days old by trypsinization, as previously described [17]. Cultured myocytes thus obtained were $>95 \%$ pure as revealed by observation of contractile characteristics with a light microscope and stained with anti-desmin antibody (Dako Cytomation, Glostrup, Denmark). Cardiomyocytes were seeded on flexible membranes base of 6 culture wells at a cell density of $1.6 \times 10^{6}$ cells/well in Ham's F-10 containing $10 \%$ horse serum and $10 \%$ fetal calf serum. After 2 days in culture, cells were transferred to serum-free medium (Ham's F-12: DMEM; 1:1) and maintained for another 2 days. The enriched myocytes were then subjected to cyclic stretch. The study conforms to Guide for the Care and Use of Laboratory Animals published by the US National Institutes of Health (NIH Publication No. 85-23, revised 1996). The study was reviewed and approved by the Institutional Animal Care and Use Committee of the Shin Kong Wu Ho-Su Memorial Hospital.

\section{In vitro cyclic stretch on cultured cardiomyocytes}

The Flexcell FX-2000 strain unit consists of a vacuum unit linked to a valve controlled by a computer program. Cardiomyocytes cultured on the flexible membrane base were subjected to cyclic stretch produced by this computer-controlled application of sinusoidal negative pressure with a peak level of $\cong 15 \mathrm{kPa}$ at a frequency of $1 \mathrm{~Hz}$ (60 cycles per min) for various periods of time. To determine the roles of c-Jun $\mathrm{N}$-terminal kinase (JNK), p38 MAP kinase or p42/p44 MAP kinase in the expression of stretch-induced TLR4 expression, cardiomyocytes were pretreated with SP600125 (20 $\mu \mathrm{M}$, CALBIOCHEM ${ }^{\circ}$, San Diego, CA, USA), SB203580 $\left(3 \mu \mathrm{M}\right.$, CALBIOCHEM $\left.{ }^{\circ}\right)$, or PD98059 $(50 \mu \mathrm{M}$,
$\mathrm{CALBIOCHEM}^{\circ}$ ) for $30 \mathrm{~min}$, respectively, followed by cyclic stretch. SP600125 is a potent, cell-permeable, selective, and reversible inhibitor of JNK. SB203580 is a highly specific, cell permeable inhibitor of p38 kinase. PD98059 is a specific and potent inhibitor of $\mathrm{p} 42 / \mathrm{p} 44$ MAP kinase. For evaluation of secreted TNF- $\alpha$ on TLR4 expression, conditioned medium from stretched cardiomyocytes and exogenous addition of TNF- $\alpha$ (100 pg/mL, R\&D Systems, Minneapolis, MN, USA) or angiotensin II (Ang II) were used to check the TLR4 protein expression by Western blot.

\section{Western blot analysis}

Western blot was performed as previously described [16]. Anti-human TLR4 human polyclonal antibody, anti-rat TNF- $\alpha$ antibody, anti-rat TNF- $\alpha$ receptor antibody (a neutralizing antibody, R\&D Systems), polyclonal anti-p38 MAP kinase and monoclonal anti-phospho p38 MAP kinase antibodies (Cell Signaling, Beverly, MA, USA), anti-mouse monoclonal NF- $\kappa$ B p 65 antibody (Santa Cruz Biotechnology, Inc., CA, USA), and polyclonal anti-phospho-NF- $\kappa$ B p65 antibody (Cell Signaling) were used. Signals were visualized by chemiluminenescent detection. Equal protein loading of the samples was further verified by staining polyclonal antibody GAPDH (LabFrontier, Seoul, Korea) or C23 monoclonal antibody (Santa Cruz Biotechnology). All Western blots were quantified using densitometry.

\section{RNA isolation and reverse transcription}

Total RNA was isolated from cells using the single-step acid guanidinium thiocyanate/phenol/chloroform extraction method. Total RNA $(1 \mu \mathrm{g})$ was incubated with 200 $\mathrm{U}$ of $\mathrm{m}$ Moloney-Murine Leukemia Virus reverse transcriptase in a buffer containing a final concentration of $50 \mathrm{mmol} / \mathrm{L}$ Tris- $\mathrm{Cl}$ (pH 8.3), $75 \mathrm{mmol} / \mathrm{L} \mathrm{KCl}, 3 \mathrm{mmol} /$ $\mathrm{MgCl}_{2}, 20 \mathrm{U}$ of RNase inhibitor, $1 \mu \mathrm{mol} / \mathrm{L}$ polydT oligomer, and $0.5 \mathrm{mmol} / \mathrm{L}$ of each $\mathrm{dNTP}$ in a final volume of $20 \mu \mathrm{L}$. The reaction mixture was incubated at $42^{\circ} \mathrm{C}$ for $1 \mathrm{~h}$ and then at $94^{\circ} \mathrm{C}$ for $5 \mathrm{~min}$ to inactivate the enzyme. A total of $80 \mu \mathrm{L}$ of diethyl pyrocarbonate treated water was added to the reaction mixture before storage at $-70^{\circ} \mathrm{C}$.

\section{Real-time Quantitative PCR}

A Lightcycler (Roche Diagnostics, Mannheim, Germany) was used for real-time PCR. The primer used for TLR4 was: forward, 5'-GGGTGAGAAACGAGCT-3'; reverse, 5'-TTGTCCTCCCACTCGA-3'. GAPDH: forward, 5'CATCACCATCTTCCAGGAGC-3'; reverse, 5'-GGATGATGTTCTGGGCTGCC-3'. Real-time RT-PCR was performed as described previously [15]. Individual PCR products were analyzed for DNA sequence to confirm the purity of the product. 


\section{RNA interference}

Cells were transfected with $800 \mathrm{ng}$ TLR4, p38, or NF- $\kappa$ B annealed siRNA (Thermo Scientific, Waltham, MA, USA). TLR4 sense and antisense of siRNA sequences were, 5'GAAAUGCCAUGAGCUUUAGUU-3' and 5'-PCUAAAGCUCAUGGCAUUUCUU-3', respectively. P38 $\alpha$ sense and antisense of siRNA sequences were 5'-GUCAUCGGUAAGCUUCUGACUU-3' and 5'-PUCAUCGGUAAGCUUCUGACUU-3', respectively. NF- $\kappa$ B sense and antisense of siRNA sequences were 5'-GGACGUGUUGCAUAUUUAAUU-3' and 5'-PUUAAAUAUGCAACACGUCCUU-3', respectively. TLR4, p38, or NF- $\kappa$ B siRNA is a target-specific 20-25 nt siRNA designed to knockdown gene expression. For negative control, a nontargeting siRNA (scrambled siRNA) purchased from Dharmacon Inc. was used. Cardiomyocytes were transfected with siRNA oligonucleotides using Effectene Transfection Reagent as suggested by the manufacture (Qiagen Inc, Valencia, CA, USA). After incubation at $37^{\circ} \mathrm{C}$ for $24 \mathrm{~h}$, cells were used for stretch, and subjected to analysis of Western blot.

\section{Electrophoretic mobility shift assay (EMSA)}

Nuclear protein concentrations from cardiomyocytes were determined by Biorad protein assay. Consensus and control oligonucleotides (Research Biolabs, Singapore) were labeled by polynucleotides kinase incorporation of [ $\gamma 32 \mathrm{P}]$-ATP. Oligonucleotides sequences included NF- $\kappa \mathrm{B}$ consensus 5'-AGTTGAGGGGACTTTCCCAGGC-3'. The NF- $\kappa$ B mutant oligonucleotides sequences were 5'AGTTGAGGCGACTTTCCCAGG-3'. After the oligonucleotide was radiolabeled, the nuclear extracts $(4 \mu \mathrm{g}$ of protein in $2 \mu \mathrm{l}$ of nuclear extract) were mixed with 20 pmol of the appropriate [ $\gamma 32 \mathrm{P}]$-ATP-labeled consensus or mutant oligonucleotide in a total volume of $20 \mu \mathrm{l}$ for $30 \mathrm{~min}$ at room temperature. The samples were then resolved on a $4 \%$ polyacrylamide gel. Gels were dried and imaged by autoradiography. Controls were performed in each case with mutant oligonucleotides or cold oligonucleotides to compete with labeled sequences.

\section{Promoter activity assay}

A -591 to +49 bp rat TLR4 promoter construct was generated as follows. Rat genomic DNA was amplified with forward primer, ACGCGTCCCCATGAACAAAC and reverse primer, AGATCTGGAACAATGCCATG. The amplified product was digested with MluI and BglII restriction enzymes and ligated into pGL3-basic luciferase plasmid vector (Promega Corp., Madison, WI, USA) digested with the same enzymes. For the mutant, the $\mathrm{NF}-\gamma \mathrm{B}$ binding sites were mutated using the mutagenesis kit (Stratagene, La Jolla, CA). Site-specific mutations were confirmed by DNA sequencing. Plasmids were transfected into cardiomyocytes using a low pressure- accelerated gene gun (Bioware Technologies, Taipei, Taiwan) essentially following the protocol from the manufacturer. Test plasmid at $2 \mu \mathrm{g}$ and control plasmid (pGL4-Renilla luciferase) $0.02 \mu \mathrm{g}$ was cotransfected with gene gun in each well, and then replaced by normal culture medium. Following stretch treatment, cell extracts were prepared using Dual-Luciferase Reporter Assay System (Promega) and measured for dual luciferase activity by luminometer (Turner Designs, Sunnyvale, CA, USA).

\section{In vitro monocyte adhesion assay}

For monocyte labeling, the human monocytic cell line THP-1 (American Type Culture Collection, Rockville, MD, USA) were suspended in phosphate-buffered saline $\left(1 \times 10^{6} / \mathrm{ml}\right)$ containing $1 \mu \mathrm{M}$ calcein-AM (Invitrogen Inc., Eugene, OR, USA) and incubated for $15 \mathrm{~min}$ at $37^{\circ} \mathrm{C}$. Labeled THP-1 cells were washed twice with phosphate-buffered saline and suspended in Hanks' buffered salt solution then added $\left(5 \times 10^{5} / \mathrm{ml}\right)$ to monolayers of stretched cardiomyocytes. After incubation and gentle rotation for $60 \mathrm{~min}$, washed with Hanks' buffered salt solution to remove unbound cells, the number of binding monocytes was counted under fluorescent microscopy.

\section{Measurement of tumor necrosis factor- $\alpha$ and angiotensin II concentration}

Conditioned media from cardiomyocytes subjected to stretch and those from control (without stretch) cells were collected for TNF- $\alpha$ and Ang II measurement. The level of TNF- $\alpha$ was measured by a quantitative sandwich enzyme immunoassay technique (R\&D Systems). The level of Ang II was measured by a quantitative sandwich enzyme immunoassay technique (Phoenix Pharmaceutical, Inc., Belmont, CA, USA). The lower limit of detection of TNF- $\alpha$ and Ang II was $5.8 \mathrm{pg} / \mathrm{mL}$ and $0.07 \mathrm{ng} /$ $\mathrm{mL}$, respectively.

\section{Statistical analysis}

The data were expressed as mean \pm SD. Statistical significance was performed with analysis of variance (GraphPad Software Inc., San Diego, CA, USA). The Dunnett's test was used to compare multiple groups to a single control group. Tukey-Kramer comparison test was used for pairwise comparisons between multiple groups after the ANOVA. A value of $\mathrm{P}<0.05$ was considered to denote statistical significance.

\section{Results}

Cyclic stretch enhances toll-like receptor 4 protein and mRNA expression in cultured cardiomyocytes

To test the effect of cyclic stretch on the TLR4 expression, $10 \%$ and $20 \%$ of cyclic stretch were used. The 
levels of TLR4 protein began to increase as early as $2 \mathrm{~h}$ (1.5-fold) after stretch at $20 \%$ elongation was applied, reached a maximum of 3.1-fold over the control by $6 \mathrm{~h}$ and maintained elevated up to $24 \mathrm{~h}$ (Fig. 1). Stretchinduced TLR4 protein expression was load-dependent. When cardiomyocytes were stretched at $10 \%$ elongation, the levels of TLR4 protein slightly increased after stretch for $2 \mathrm{~h}$ and did not increase significantly as compared to control cells without stretch from 2 to $24 \mathrm{~h}$ (Fig. 1A and 1B). The levels of TLR4 mRNA also significantly increased from $2 \mathrm{~h}$ to $24 \mathrm{~h}$ after $20 \%$ of cyclic stretch (Fig. 1C). As shown in Additional file 1, cyclic stretch for 2 to $6 \mathrm{~h}$ also increased Ang II and TNF- $\alpha$ receptors protein expression in cardiomyocytes. This finding indicates that cyclic stretch could induce activations of Ang II and TNF- $\alpha$ receptors in cardiomyocytes.

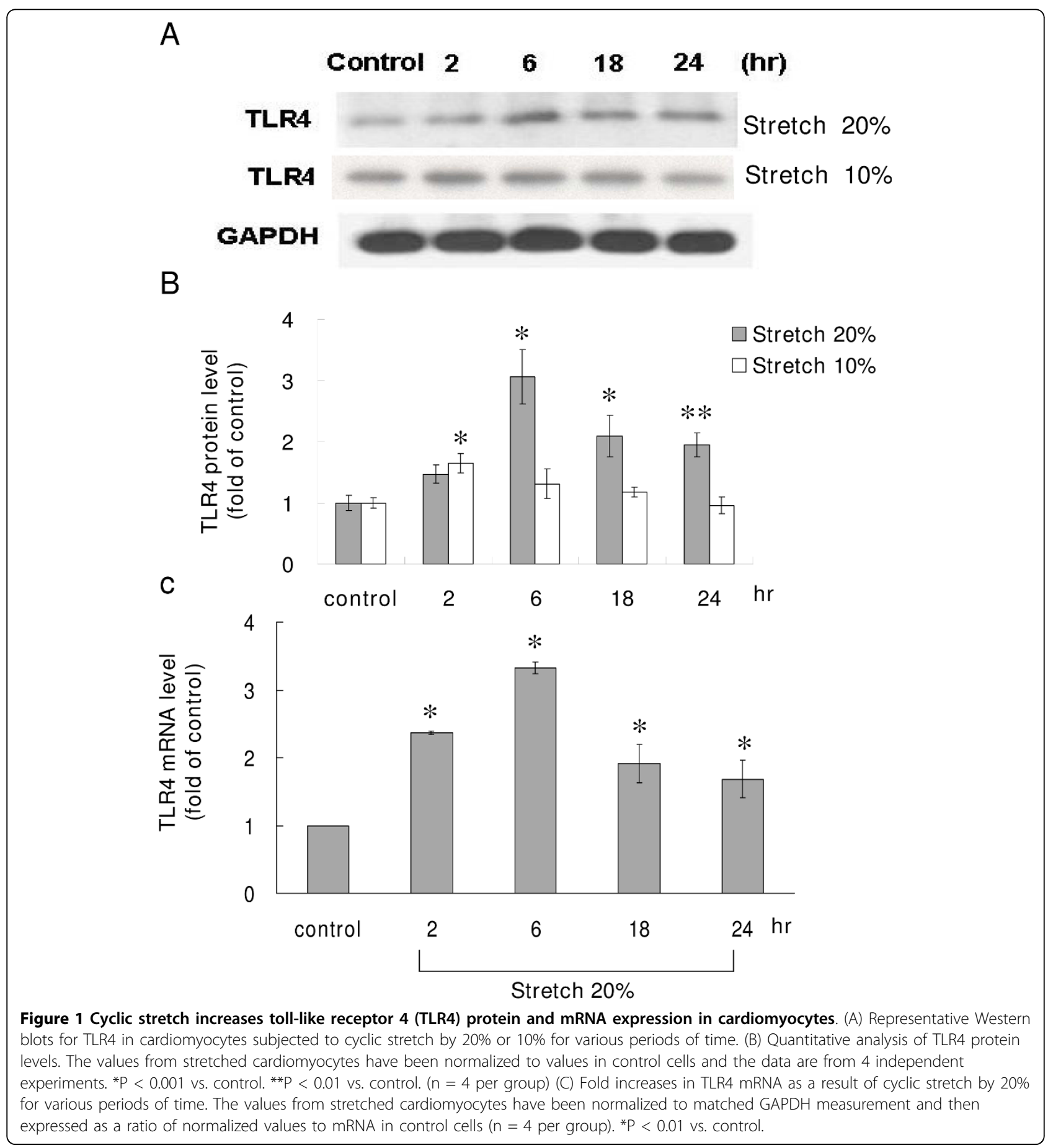


Cyclic stretch-induced TLR4 protein expression in cardiomyocytes is mediated by p38 MAP kinase and TNF- $\alpha$ To investigate the possible signaling pathways mediating the stretch-induced TLR4 expression, different inhibitors were used. As shown in Fig. 2, the Western blots demonstrated that cyclic stretch-induced increase of TLR4 protein was significantly attenuated after addition of SB203580 before stretch. The TLR4 protein induced by stretch was partially attenuated by the addition of PD98059. DMSO as the vehicle for PD98059 did not affect TLR4 expression induced by stretch. P38 $\alpha$ siRNA completely blocked the TLR4 expression induced by stretch. The control siRNA did not affect the TLR4 expression induced by stretch. As shown in Fig. 3, phosphorylated p38 protein was maximally induced at $6 \mathrm{~h}$ after cyclic stretch and remained elevated until $18 \mathrm{~h}$. The phosphorylated p38 protein was abolished by pretreatment with SB203580. P38 siRNA knocked down the p38 protein expression by 67\% (from 2.4-fold to 0.8-fold). These findings indicate that p38 MAP kinase pathway is an important regulator to mediate the TLR4 expression induced by cyclic stretch in cardiomyocytes.

Exogenous addition of TNF- $\alpha$ at $100 \mathrm{pg} / \mathrm{mL}$ significantly increased TLR4 protein expression as compared to control cells (Fig. 2). Conditioned medium from stretched cardiomyocytes also significantly induced TLR4 protein expression. Addition of TNF- $\alpha$ antibody $(5 \mu \mathrm{g} / \mathrm{mL}) 30 \mathrm{~min}$ before cyclic stretch completely inhibited the increase of TLR4 induced by cyclic stretch. Addition of goat IgG $30 \mathrm{~min}$ before cyclic stretch did not affect the protein expression of TLR4 induced by cyclic stretch. Addition of TNF- $\alpha$ receptor antibody $(5 \mu \mathrm{g} / \mathrm{mL}) 30 \mathrm{~min}$ before stretch also significantly attenuated the increase of TLR4 induced by stretch (data not shown). This finding indicates that TNF- $\alpha$ may directly mediate the increase of TLR4 by cyclic stretch. As shown in Fig. 4, addition of losartan (100 nM) before stretch significantly inhibited the increase of TLR4 protein expression induced by stretch. Addition of losartan $(100 \mathrm{nM})$ before TNF- $\alpha$ use significantly inhibited the increase of TLR4 protein expression induced TNF- $\alpha$.
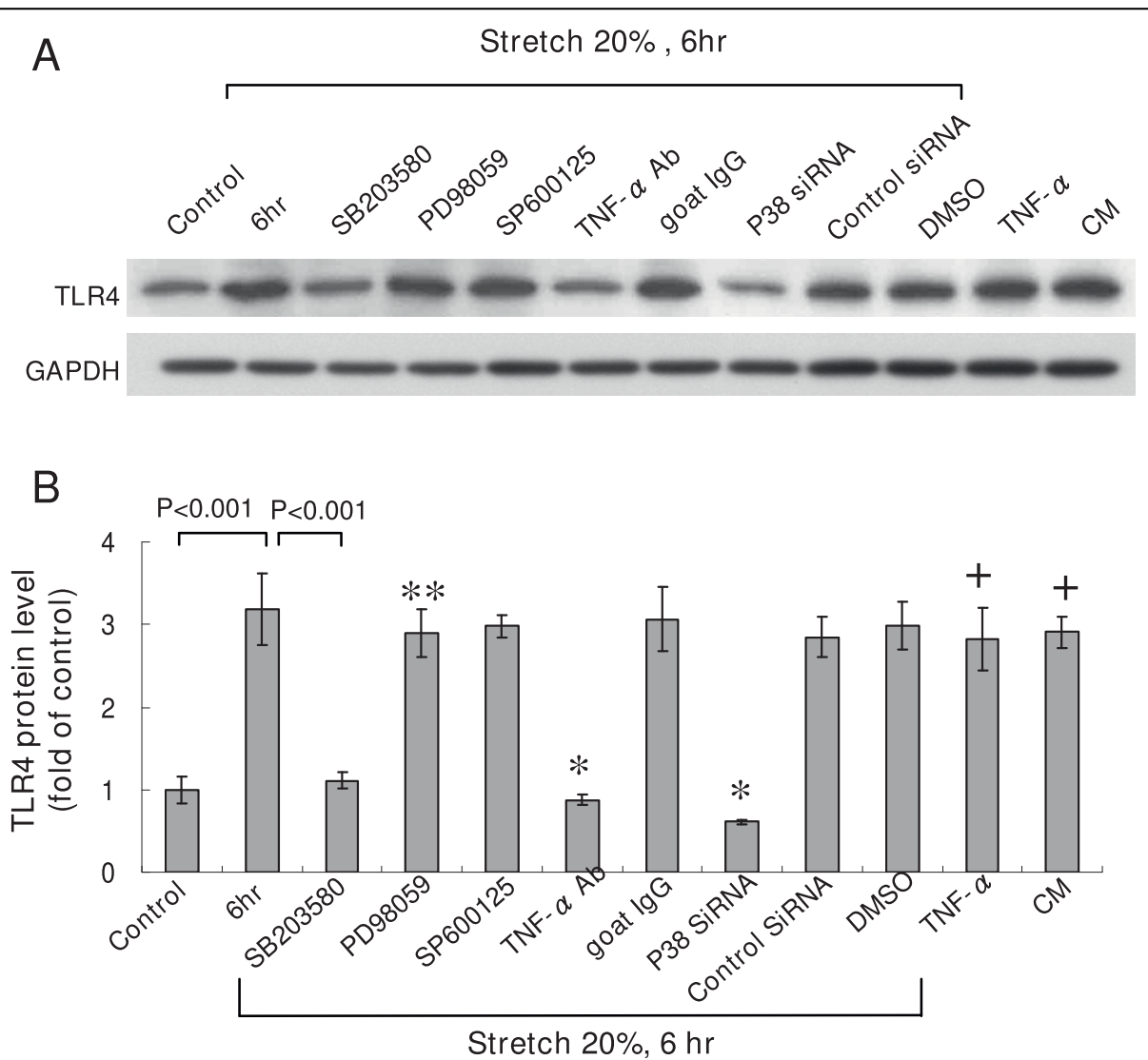

Figure 2 p38 MAP kinase and tumor necrosis factor- $\alpha$ (TNF- $\alpha$ ) are important regulators that mediate stretch-induced TLR4 expression in cardiomyocytes. (A) Representative Western blots for TLR4 protein levels in cardiomyocytes subjected to cyclic stretch for $6 \mathrm{~h}$ or control cells without stretch in the absence or presence of different inhibitors, and siRNA. CM indicates conditioned medium. (B) Quantitative analysis of TLR4 protein levels. The values from stretched cardiomyocytes have been normalized to values in control cells ( $n=4$ per group). ${ }^{*} P<0.001$ vs. stretch 6 h. ${ }^{* * P}<0.01$ vs. stretch 6 h. ${ }^{+} \mathrm{P}<0.001$ vs. control. 


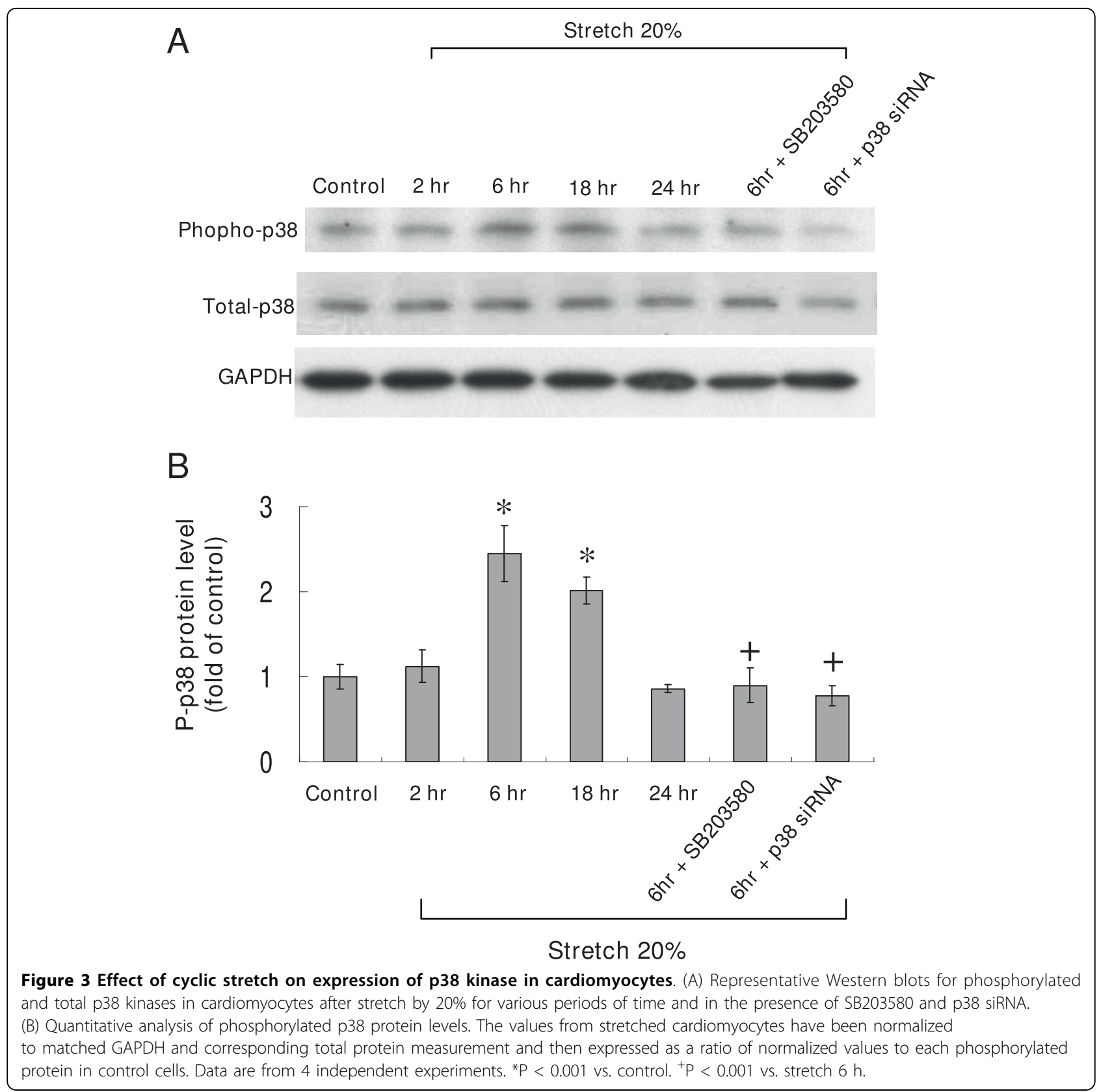

Exogenous addition of Ang II significantly induced TLR4 protein expression. Addition of TNF- $\alpha$ antibody $30 \mathrm{~min}$ before addition of Ang II did not affect the TLR4 protein expression. Cyclic stretch significantly increased the TNF- $\alpha$ secretion from myocytes from $2 \mathrm{~h}$ to $18 \mathrm{~h}$ after stretch (Fig. 5A). The mean concentration of TNF- $\alpha$ rose from $47.9 \pm 10.5 \mathrm{pg} / \mathrm{mL}$ before stretch to $179 \pm 25 \mathrm{pg} / \mathrm{mL}$ after stretch for $2 \mathrm{~h}(\mathrm{P}<0.01)$. Cyclic stretch also significantly increased Ang II secretion from cardiomyocytes from $2 \mathrm{~h}$ to $24 \mathrm{~h}$ after stretch (Fig. 5B). The mean concentration of Ang II rose from $41.7 \pm 8.4$ $\mathrm{ng} / \mathrm{mL}$ before stretch to $185.9 \pm 34.9 \mathrm{ng} / \mathrm{mL}$ after stretch for $2 \mathrm{~h}(\mathrm{P}<0.01)$. Addition of TNF- $\alpha$ increased Ang II secretion from cardiomyocytes, while addition of TNF- $\alpha$ antibody significantly inhibited the Ang II secretion from stretched cardiomyocytes. These data indicate that cyclic stretch increases TLR4 protein expression through angiotensin receptor by Ang II and Ang II is secreted from cardiomyocytes by TNF- $\alpha$ stimulation. P38 siRNA attenuated the TLR4 expression induced by exogenous addition of Ang II, indicating Ang II receptor was activated before p38 MAP kinase. Combined these findings, our data indicate that cyclic stretch first increases TNF- $\alpha$ expression, then stimulates Ang II 


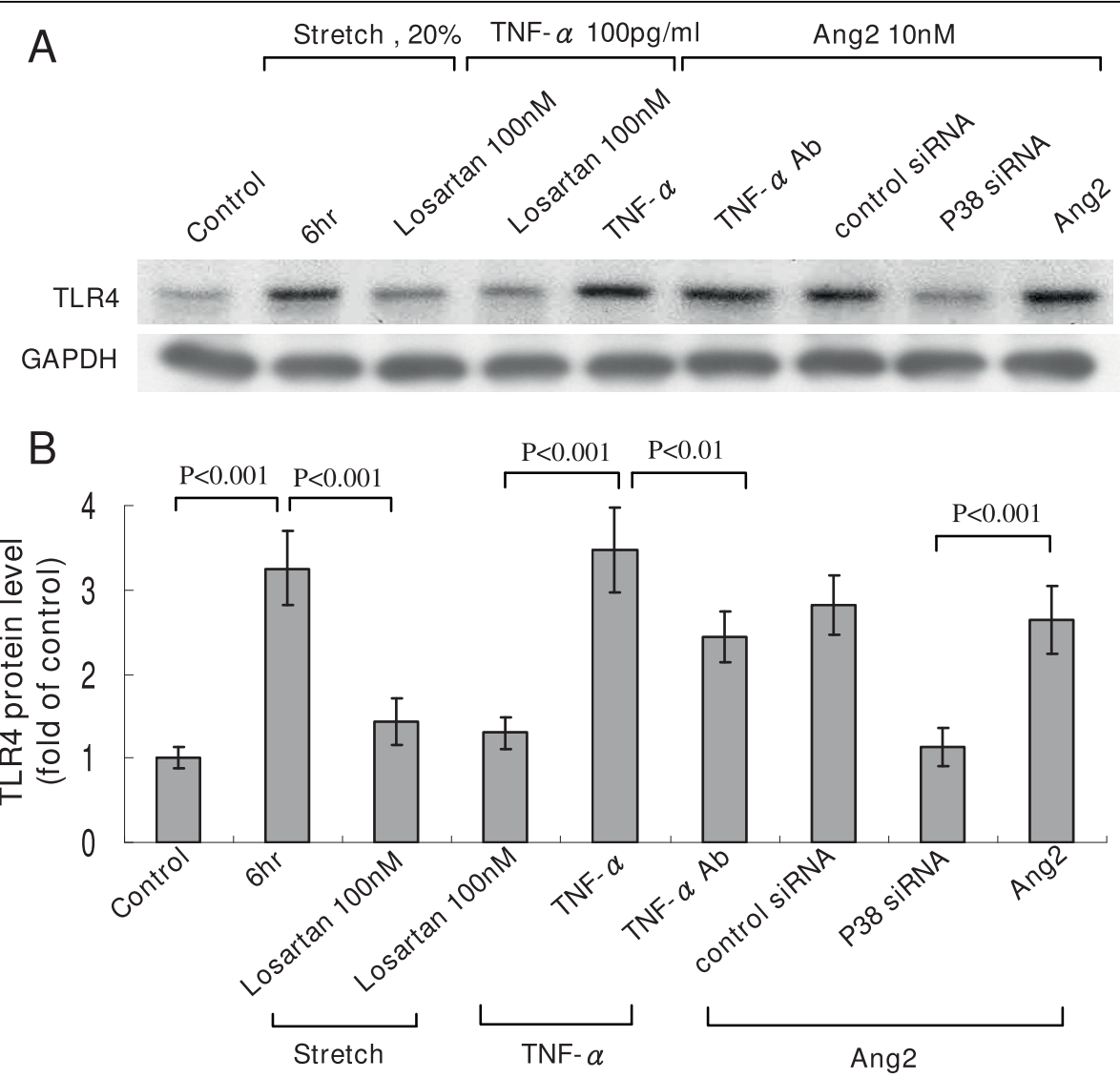

Figure 4 Angiotensin II mediates the increase of TLR4 by cyclic stretch through angiotensin II receptor. (A) Representative Western blots for TLR4 in cardiomyocytes subjected to cyclic stretch by $20 \%$ for 6 h or without stretch in the presence or absence of inhibitors. (B) Quantitative analysis of TLR4 protein levels. The values from stretched cardiomyocytes have been normalized to values in control cells and the data are from 4 independent experiments.

expression, which subsequently activates p38 MAP kinase and induces phosphorylation of NF- $\kappa$ B (Fig. 6) in cardiomyocytes.

\section{Cyclic stretch increases NF- $\kappa$ B-binding activity and $\mathrm{NF}-\kappa \mathrm{B}$ phosphorylation}

Cyclic stretch of cultured cardiomyocytes for 2 to $24 \mathrm{~h}$ significantly increased the DNA-protein binding activity of NF- $\kappa$ B (Fig. 6A). An excess of unlabeled NF- $\kappa$ B oligonucleotide competed with the probe for binding NF$\kappa \mathrm{B}$ protein, whereas an oligonucleotide containing a 2bp substitution in the NF- $\kappa \mathrm{B}$ binding site did not compete for binding. Addition of SB203580, Ang II receptor antagonist with losartan, and TNF- $\alpha$ antibody $30 \mathrm{~min}$ before stretch abolished the DNA-protein binding activity induced by stretch (Fig. 6A). Our finding indicates that Ang II receptor-related mechanism is involved in cyclic stretch-induced NF- $\kappa \mathrm{B}$ activity. DNA-binding complexes induced by cyclic stretch could be supershifted by a specific p65 antibody (a specific antibody for NF- $\kappa \mathrm{B}$ ), indicating the presence of this protein in these complexes. Cyclic stretch significantly increased phosphorylation of NF- $\kappa \mathrm{B}$ as compared to control cells without stretch (Fig. 6B and 6C). The increased phosphorylation of NF- $\kappa$ B induced by stretch was significantly attenuated by addition of SB203580 $30 \mathrm{~min}$ before stretch. Addition of losartan or TNF- $\alpha$ receptor antibody $30 \mathrm{~min}$ before stretch abolished the phosphorylation of NF- $\kappa \mathrm{B}$ induced by stretch (Fig. $6 \mathrm{~B}$ and $6 \mathrm{C}$ ), indicating Ang II and TNF- $\alpha$ receptors are involved in cyclic stretch-induced NF- $\kappa \mathrm{B}$ phosphorylation.

\section{Cyclic stretch increases TLR4 promoter activity}

The rat TLR4 promoter construct contains HIF- $1 \alpha$, AP1 , and NF- $\kappa \mathrm{B}$ binding sites. Cyclic stretch for $2 \mathrm{~h}$ significantly increased the TLR 4 promoter activity by 4.2 -fold as compared to control without stretch (Fig. 7). Addition of SB203580 and NF- $\kappa$ B siRNA, losartan $30 \mathrm{~min}-$ utes before stretch abolished the increased TLR4 promoter. When the NF- $\kappa \mathrm{B}$ binding sites were mutated, the increased promoter activity induced by cyclic stretch was abolished. Exogenous addition of AngII increased 


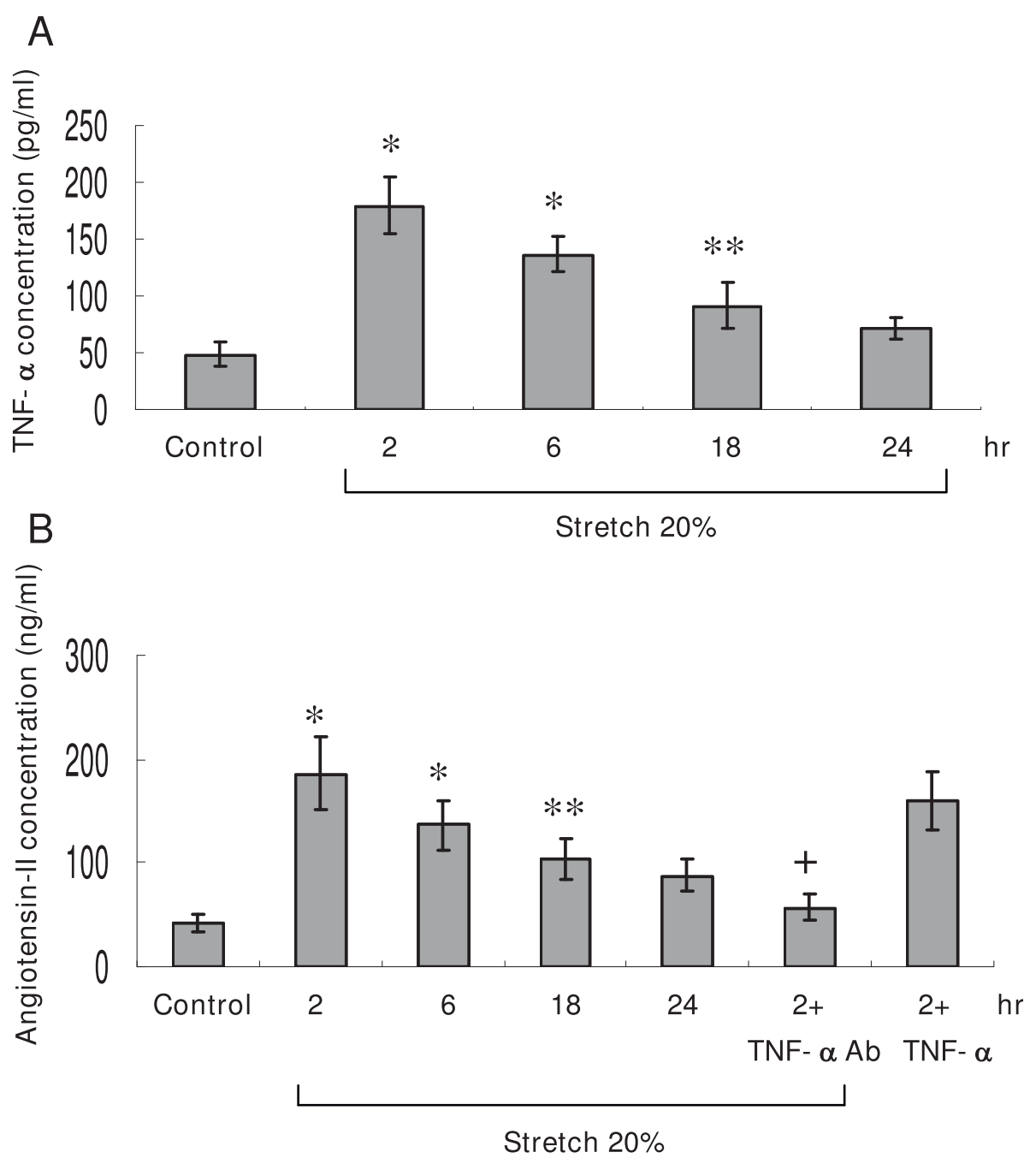

Figure 5 Cyclic stretch increases release of TNF- $\alpha$ and angiotensin II (Angll) from cardiomyocytes subjected to $20 \%$ of stretch for various periods of time. The cultured medium were collected for measurement of TNF- $\alpha$ (A) and Ang II (B) in cultured cardiomyocytes after stretch for various periods of time via immunoassay $(n=4) .{ }^{*} P<0.001$ vs. control. ${ }^{*} P<0.05$ vs. control. ${ }^{+} P<0.001$ vs. stretch $2 \mathrm{~h}$.

the TLR4 promoter activity similar to cyclic stretch. This finding indicates that cyclic stretch regulates TLR4 in cardiomyocytes at transcriptional level and that NF$\kappa \mathrm{B}$ binding site in the TLR4 promoter is essential for the transcriptional regulation.

\section{Cyclic stretch increases monocyte adhesion}

To test the function of increased TLR4 expression after cyclic stretch in cardiomyocytes, we performed monocyte adhesion assay. Monocyte adhesion to cardiomyocytes significantly increased after 6 h of stretch (2.7fold) as compared to control cells without stretch (Fig. 8). Addition of SB203580, TNF- $\alpha$ antibody, and TLR-4 siRNA $30 \mathrm{~min}$ before stretch significantly attenuated the adhesion of monocyte to cardiomyocytes induced by stretch.

\section{Discussion}

In this study, we demonstrated several significant findings. First, cyclic stretch up-regulates TLR4 expression in cardiomyocytes; second, TNF- $\alpha$ and AngII act as an autocrine factor to mediate the increased TLR4 expression induced by cyclic stretch; third, p38 MAP kinase and NF- $\kappa \mathrm{B}$ transcription factor are involved in the signaling pathway of TLR4 induction, fourth, the increased TLR4 by stretch increases monocyte adhesion to cardiomyocytes. TLR4 in cardiomyocytes was up-regulated in both a time- and load-dependent manner by cyclic stretch. Our data clearly indicate that hemodynamic forces play a crucial role in the modulation of TLR4 expression in cardiomyocytes. Our data also demonstrated that functional consequence of TLR4 up-regulation by stretch resulted in adhesion of monocytes. TLR4 


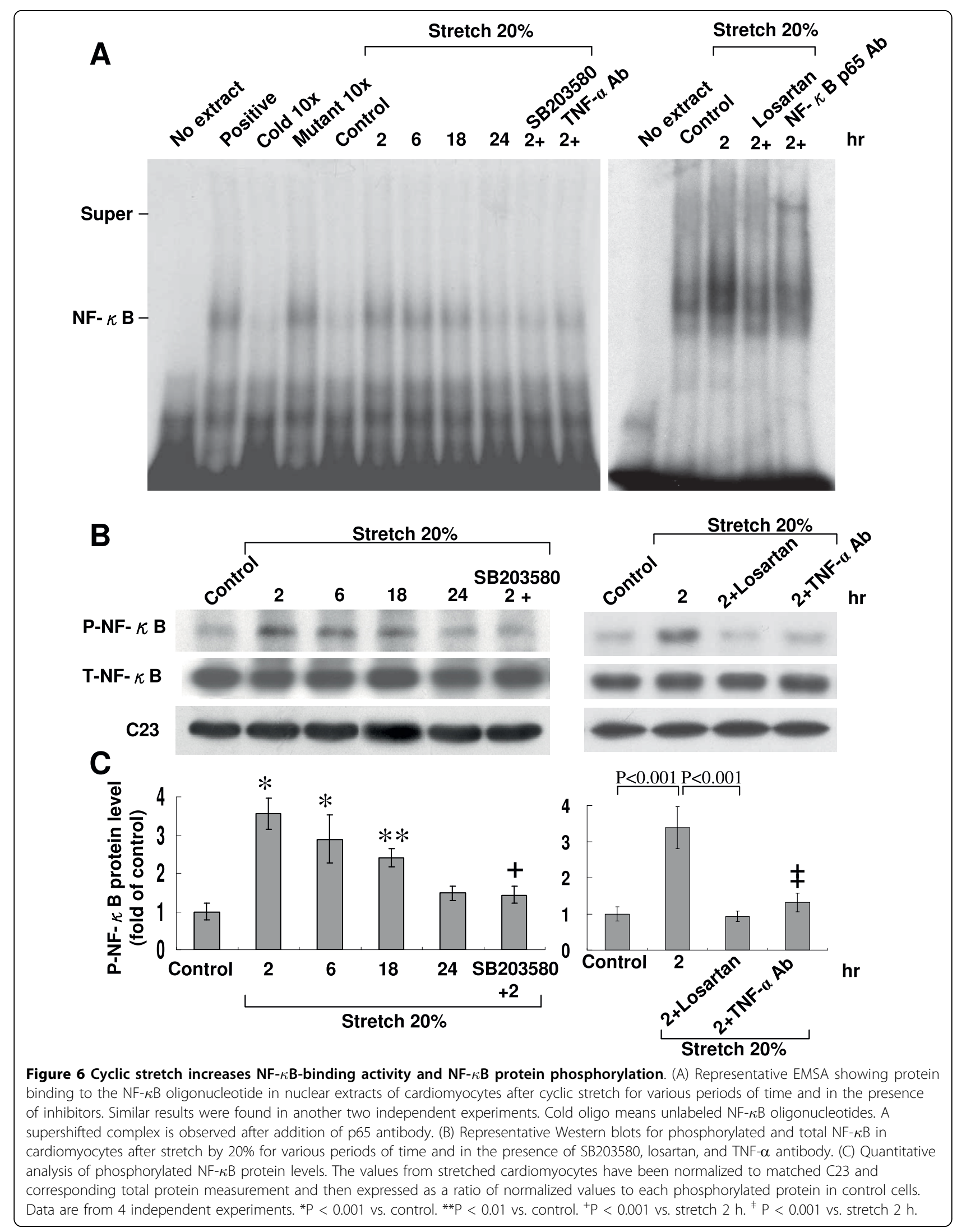




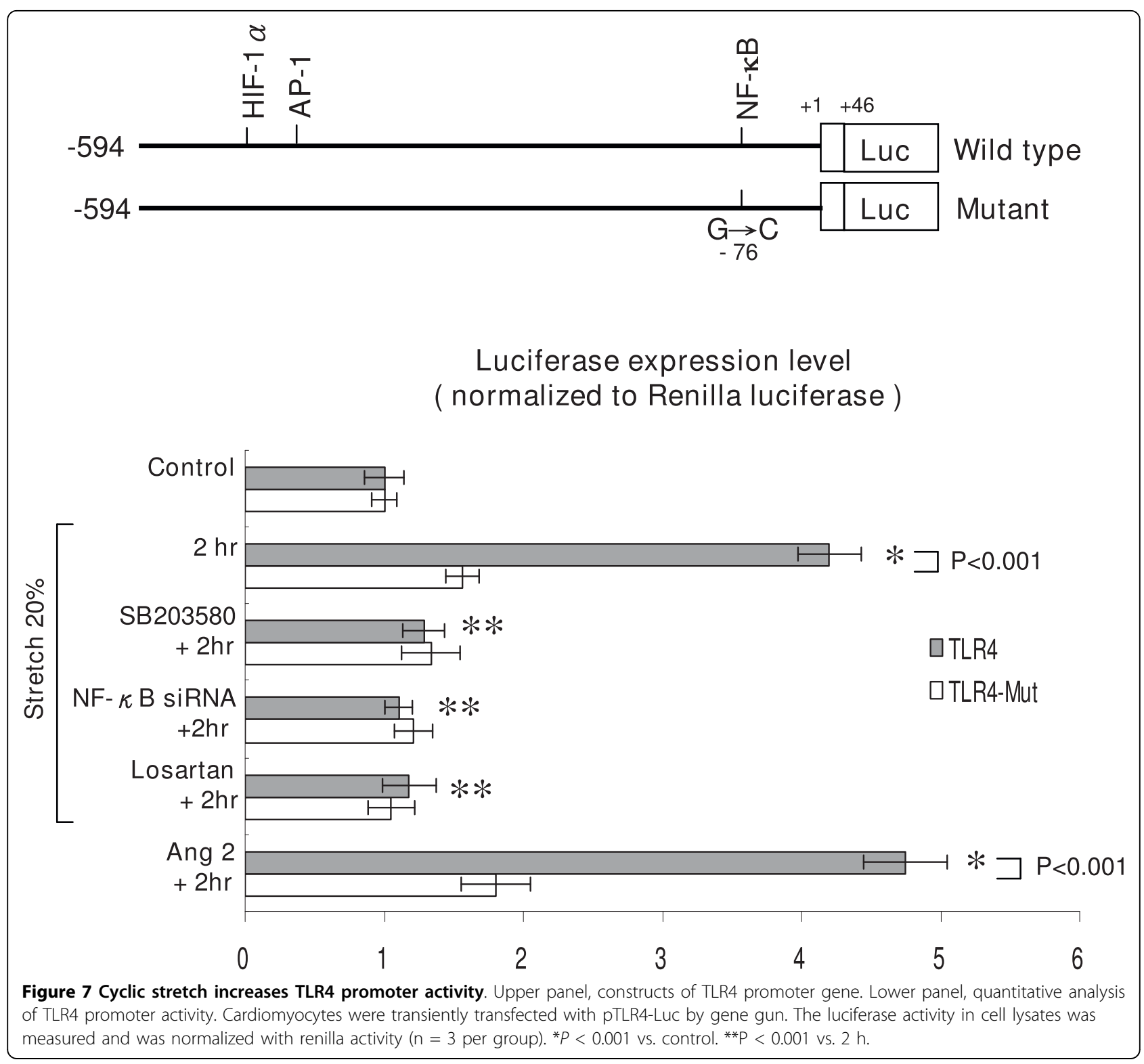

may activate monocyte activation to play host defense function [18]. However, the activated monocytes may decrease contractility of cardiomyocytes $[19,20]$. Left ventricular end-diastolic pressure is elevated in most of the diseased heart. The elevated end-diastolic pressure will stretch the myocardium. Therefore, the adherent monocytes to cardiomyocytes induced by stretch may worsen the ventricular function in diseased heart.

The induction of TLR4 protein by cyclic stretch was largely mediated by p38 MAP kinase pathway because the specific and potent inhibitors of an upstream p38 kinase, SB203580 inhibited the induction of TLR4 protein. This signaling pathway of p38 was further confirmed by the finding that p38 siRNA inhibited the induction of TLR4 protein by cyclic stretch. The NF- $\kappa \mathrm{B}$ binding activity and TLR4 promoter activity induced by cyclic stretch were attenuated by p38 inhibitor, indicating p38 MAP kinase plays an important role in the regulation of TLR4 expression by cyclic stretch in cardiomyocytes. TLR4 mediates through a phosphoinositide 3-kinase dependent pathway, not through p38 MAP kinase to protect against myocardial ischemia/ reperfusion injury [21]. Recently, Bruns et al. have demonstrated that TLR4 inactivation resulted in an attenuation of several responses, including p38 MAP kinase phosphorylation and NF- $\kappa \mathrm{B}$ nuclear translocation, which resulted in preventing burn-induced myocardial contractile dysfunction [22]. These data indicate that different signaling pathways may mediate TLR4 expression on cardiomyocytes in different stress states. 


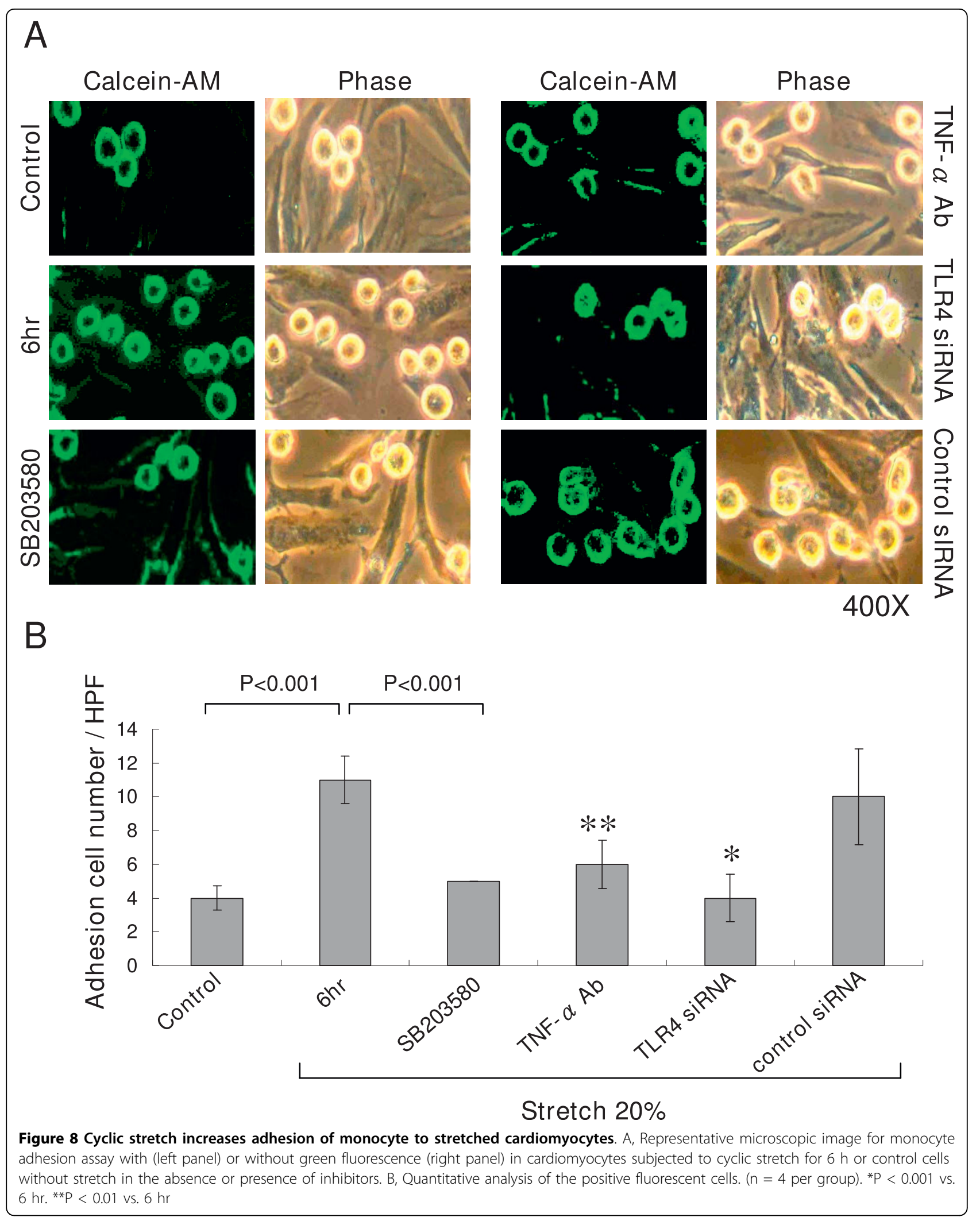


Mechanical stretch may induce secretion or synthesis of bioactive molecules from cardiomyocytes [23]. Wolf et al. have reported that AngII up-regulates TLR4 on mesanginal cells [24]. However, the link between TLR4 and AngII in cardiomyocytes has yet not been reported. TNF- $\alpha$ and interleukin- 1 have been linked to TLR4 to mediate postischemic cardiac dysfunction [2]. In the present study, we have demonstrated that stretched cardiomyocytes secrete TNF- $\alpha$ and AngII. Exogenous addition of TNF- $\alpha$ or AngII increased TLR4 expression in cardiomyocytes. TNF- $\alpha$ monoclonal antibody and TNF$\alpha$ receptor antibody blocked the increases of TLR4 protein induced by cyclic stretch. Losartan, an antagonist of AngII receptor attenuated the TLR4 protein expression induced by cyclic stretch and TNF- $\alpha$, indicating that TNF- $\alpha$ works before AngII to induce TLR expression and AngII works through AngII receptor to enhance TLR4 expression in cardiomyocytes. This was confirmed by the finding that TNF- $\alpha$ increased AngII secretion and TNF- $\alpha$ antibody blocked the secretion of AngII secretion. These results provide the first evidence for TNF- $\alpha$ and AngII mediating cyclic stretch-induced expression of TLR4 in cardiomyocytes. These results further confirmed the autocrine or paracrine production of cardiomyocytes in response to cyclic stretch.

TLRs are a family of molecules that play a critical role in innate immunity. Among TLRs, TLR4, the receptor for lipopolysaccharide, is the most frequently observed and best-characterized receptor. In addition to playing a role in heart failure and myocardial ischemia/reperfusion injury, TLR4 has been found to play a role in neointimal formation, atherosclerosis [25] and stroke [26]. NF- $\kappa$ B is a critical transcription factor in TLRs-mediated signaling pathways [27]. In this study, we demonstrated that cyclic stretch stimulation of NF- $\kappa \mathrm{B}$-DNA binding activity required at least phosphorylation of the $\mathrm{p} 38$ since $\mathrm{p} 38$ inhibitor abolished the NF- $\kappa \mathrm{B}$ binding activity. The phosphorylation of NF- $\kappa$ B protein was enhanced by cyclic stretch and was attenuated by p38 inhibitor. We further demonstrated that cyclic stretch increased TLR4 promoter activity and the binding site of NF- $\kappa \mathrm{B}$ in the TLR4 promoter is essential for the transcriptional regulation. Our data indicate that NF- $\kappa \mathrm{B}$ plays an important role in the regulation of TLR4 by cyclic stretch in cardiomyocytes.

\section{Conclusions}

Our study reports for the first time that cyclic stretch enhances TLR4 expression in cultured rat cardiomyocytes. The stretch-induced TLR4 is mediated through TNF- $\alpha$, AngII, p38 kinase and NF- $\kappa$ B pathway. TLR4 increases adhesion of monocytes to stretched myocytes. The TLR4 induced by cyclic stretch may contribute to the host defense of cardiomyocytes under hemodynamic overload.
Additional file 1: Supplementary figure. Cyclic stretch increases angiotensin II receptor (Ang II-R) and tumor necrosis factor- $\alpha$ receptor (TNF- $\alpha-R$ ) protein expression in cardiomyocytes. (A) Representative Western blots for Ang II-R and TNF- $\alpha-R$ in cardiomyocytes subjected to cyclic stretch by $20 \%$ for various periods of time. (B) Quantitative analysis of Ang II-R and TNF- $\alpha-R$ protein levels. The values from stretched cardiomyocytes have been normalized to values in control cells and the data from 4 independent experiments. ${ }^{*} P<0.001$ vs. control. ${ }^{*} P<0.05$ vs. control. ( $n=4$ per group).

Click here for file

[http://www.biomedcentral.com/content/supplementary/1423-0127-1715-S1.PPT]

\section{List of abbreviations used}

Ang II: angiotensin II; EMSA: electrophoretic mobility shift assay; NF- $\kappa \mathrm{B}$ : nuclear factor-kappa B; siRNA: small interfering RNA; TLR: toll-like receptor; TNF- $\alpha$ : tumor necrosis factor- $\alpha$.

\section{Acknowledgements}

This study was sponsored in part from National Science Council, Executive Yuan, Taiwan and Shin Kong Wu Ho-Su Memorial Hospital, Taipei, Taiwan.

\section{Author details}

'Division of Cardiology, Shin Kong Wu Ho-Su Memorial Hospital, Taipei, Taiwan. ${ }^{2}$ Graduate Institute of Medical Sciences, College of Medicine, Taipei Medical University, Taipei, Taiwan. ${ }^{3}$ School of Medicine, Fu-Jen Catholic University, Taipei, Taiwan. ${ }^{4}$ Department of Emergency Medicine, Shin Kong Wu Ho-Su Memorial Hospital, Taipei, Taiwan.

\section{Authors' contributions}

K-GS has participated in the design of the study and drafted the manuscript. B-WW has made substantial contributions to conception and design, or acquisition of data, or analysis and interpretation of data. C-ML has made substantial contributions to conception and design, or acquisition of data, or analysis and interpretation of data. HC has given final approval of the version to be published.

\section{Competing interests}

The authors declare that they have no competing interests.

Received: 26 November 2009 Accepted: 5 March 2010

Published: 5 March 2010

\section{References}

1. Medzhitov R, Preston-Hurlburt P, Janeway CA: A human homologue of the Drosophila Toll protein signals activation of adaptive immunity. Nature 1997, 388:394-397.

2. Cha J, Wang Z, Ao L, Zou N, Dinarello CA, Banerjee A, Fullerton DA, Meng X: Cytokines link Toll-like receptor 4 signaling to cardiac dysfunction after global myocardial ischemia. Ann Thorac Surg 2008, 85:1678-1685.

3. Frantz S, Kobzik L, Kim YD, Fukazawa R, Medzhitov R, Lee RT, Kelly RA: Toll4 (TLR4) expression in cardiac myocytes in normal and failing myocardium. J Clin Invest 1999, 104:271-280.

4. Boyd JH, Mathur S, Wang Y, Bateman RM, Walley ER: Toll-like receptor stimulation in cardiomyocytes decreases contractility and initiates an NFkappaB dependent inflammatory response. Cardiovasc Res 2006, 72:384-393.

5. Oyama J, Blais C jr, Liu X, Pu M, Kobzik L, Kelly RA, Bourcier T: Reduced myocardial ischemia-reperfusion injury in toll-like 4-deficient mice. Circulation 2004, 109:784-789.

6. Samantha A, Tavener SA, Kubes P: Is there a role for cardiomyocyte tolllike receptor 4 in endotoxemia?. Trends Cardiovasc Med 2005, 15:153-157.

7. Tavener SA, Long EM, Robbins SM, McRae KM, Van Remmen H, Kubes P: Immune cell toll-like receptor 4 is required for cardiac myocyte impairment during endotoxemia. Circ Res 2004, 95:700-707.

8. Ha T, Li Y, Hua F, Ma J, Gao X, Kelley J, Zhao A, Haddad GE, Williams DL, Browder IW, Kao RL, Li C: Reduced cardiac hypertrophy in toll-like 
receptor 4-deficient mice following pressure overload. Cardiovasc Res 2005, 68:224-234.

9. Raid A, Bien S, Gratz M, Escher F, Westermann D, Heimesaat MM, Bereswill S, Krieg T, Felix SB, Schultheiss HP, Kroemer HK, Tschope C: Tolllike receptor-4 deficiency attenuates doxorubicin-induced cardiomyopathy in mice. Eur J Heart Fail 2008, 10:233-243.

10. Comstock KL, Krown KA, Page MT, Martin D, Ho P, Pedraza M, Castro EN, Nakajima N, Glembotski CC, Quintana PJ, Sabbadini RA: LPS-induced TNFalpha release from and apoptosis in rat cardiomyocytes: obligatory role for CD14 in mediating the LPS response. J Mol Cell Cardiol 1998, 30:2761-2775.

11. Wright G, Singh IS, Hasday JD, Farrance IK, Hall G, Cross AS, Rogers TB: Endotoxin stress-response in cardiomyocytes: NF-kappaB activation and tumor necrosis factor-alpha expression. Am J Physiol Heart Circ Physiol 2002, 282:H872-H879.

12. Anker SD, van Haehling: Inflammatory mediators in chronic heart failure: an overview. Heart 2004, 90:464-470.

13. Linde A, Mosier D, Blecha F, Melgarejo T: Innate immunity and inflammation-new frontiers in comparative cardiovascular pathology. Cardiovasc Res 2007, 73:26-36.

14. Kuwahara F, Kai H, Tokuda K, Niiyama H, Tahara N, Kusaba K, Takemiya K, Jalalidin A, Koga M, Nagata T, Shibata R, Imaizumi T: Roles of intercellular adhesion molecule-1 in hypertensive cardiac remodeling. Hypertension 2003, 41:819-823.

15. Chang H, Wang BW, Kuan P, Shyu KG: Cyclical mechanical stretch enhances angiopoietin-2 and Tie2 receptor expression in cultured human umbilical vein endothelial cells. Clin Sci 2003, 104:421-428.

16. Shyu KG, Chao YM, Wang BW, Kuan P: Regulation of discoidin domain receptor 2 by cyclic mechanical stretch in cultured rat vascular smooth muscle cells. Hypertension 2005, 46:614-621.

17. Shyu KG, Chen CC, Wang BW, Kuan PL: Angiotensin II receptor antagonist blocks the expression of connexin43 induced by cyclical mechanical stretch in cultured neonatal rat cardiac myocytes. J Mol Cell Cardiol 2001, 33:691-698.

18. Sabroe I, Dower SK, Whyte MKB: The role of toll-like receptors in the regulation of neutrophil migration, activation, and apoptosis. Clin Infect Dis 2005, 41:S421-S426.

19. Simms MG, Walley KR: Activated macrophages decrease rat cardiac myocyte contractility: importance of ICAM-1-dependnet adhesion. Am J Physiol Heart Circ Physiol 1999, 277:H253-H260.

20. Tavener $S$, Kubes P: Cellular and molecular mechanisms underlying LPSassociated myocyte impairement. Am J Physiol Heart Circ Physiol 2006, 290:H800-H806.

21. Hua F, Ha T, Ma J, Li Y, Kelley J, Gao X, Browder IW, Kao RL, Williams DL, Li C: Protection against myoocardial ischemia/reperfusion injury in TLR4deficient mice is mediated through a phosphoinostide 3-kinasedependent mechanism. J Immunol 2007, 178:7317-7324.

22. Bruns B, Maass D, Barber R, Horton J, Carison D: Alteration in the cardiac inflammatory response to burn trauma in mice lacking a functiona; tolllike receptor 4 gene. Shock 2008, 30:740-746.

23. Shyu KG: Cellular and molecular effects of mechanical stretch on vascular cells and cardiac myocytes. Clin Sci 2009, 116:377-389.

24. Wolf $\mathrm{G}$, Bohlender J, Bondeva T, Roger T, Thaiss F, Wenzel UO: Angiotensin II upregulates toll-like receptor 4 on mesanginal cells. J Am Soc Nephrol 2006, 17:1585-1593.

25. De Kleijn D, Pasterkamp G: Toll-liker receptors in cardiovascular diseases. Cardiovasc Res 2003, 60:58-67.

26. Caso JR, Pradillo JM, Hurtado O, Lorenzo P, Moro MA, Lizasoain I: Toll-like receptor 4 is involved in brain damage and inflammation after experimental stroke. Circulation 2007, 115:1599-1608.

27. Zhang G, Ghosh S: Toll-like receptor-mediated NF- $\kappa$ B activation: a phylogenetically conserved paradigm in innate immunity. J Clin Invest 2001, 107:13-19.

doi:10.1186/1423-0127-17-15

Cite this article as: Shyu et al.: Cyclic stretch enhances the expression of Toll-like Receptor 4 gene in cultured cardiomyocytes via p38 MAP kinase and NF- $\kappa$ B pathway. Journal of Biomedical Science 2010 17:15.

\section{Submit your next manuscript to BioMed Central and take full advantage of:}

- Convenient online submission

- Thorough peer review

- No space constraints or color figure charges

- Immediate publication on acceptance

- Inclusion in PubMed, CAS, Scopus and Google Scholar

- Research which is freely available for redistribution

Submit your manuscript at www.biomedcentral.com/submit
Biomed Central 